\title{
Nutritional Quality Evaluation of Stored Onion (Allium cepa L.) Powder in Transparent and Amber Coloured Jars
}

\author{
${ }^{* 1}$ I. Bala, ${ }^{1}$ F.U. Ahmad, ${ }^{1}$ A.K. Yerima, ${ }^{2}$ S. S. Said and ${ }^{1}$ A.T. Ibrahim \\ ${ }^{1}$ Nigerian Stored Products Research Institute, P.M.B. 3032, Kano State \\ ${ }^{2}$ Department of Biochemistry and Molecular Biology, Federal University, Dutain-Ma, P.M.B 5001, Katsina State
}

[*Corresponding Author: E-mail: binbala04@gmail.com]

\section{ABSTRACT}

This study investigated the proximate compositions, microbial counts and total polyphenols content of onion powder stored at ambient temperature for six months in transparent and amber coloured jars. Standard methods of Association of Analytical Chemists (AOAC), American Public Health Association (APHA) were used to evaluate the proximate composition and microbial count of the powder while the Folin-Ciocalteu method was used to assess total polyphenols during and after storage. There were significant $(p<0.05)$ differences in the total polyphenol (TP) contents and proximate composition of onion powder stored in amber and transparent jars. Total polyphenol contents of the onion powder decreased from an initial value of $14.60 \pm 1.08 \mathrm{mg} / \mathrm{g}$ GAE to a final value of $5.92 \pm 0.76 \mathrm{mg} / \mathrm{g}$ GAE in the amber coloured jar after storage while a final value of $1.64 \pm 0.78(\mathrm{mg} / \mathrm{g}) \mathrm{GAE}$ was evaluated after storage in the transparent jar. From proximate compositions, only crude protein, fibre and moisture contents increased during and after storage in both storage jars. There was more retention of proximate parameters in the content of amber storage jar during and after storage. Microbial colony counts in onion powder in the amber jars were fewer than in the transparent jars during and after storage. To minimize wastage of onion during glut season, onion should be made into powder form and better stored in amber coloured material for better retention of nutritional qualities prior to use at home or industry.

Keywords: Onion, Powder, Nutritional Quality, Storage

\section{INTRODUCTION}

Onion (Allium cepa L.) which belongs to the lily family Amaryllidaceae is a herbaceous and highly perishable crop whose post-harvest value addition can be enhanced through dehydration (Jayeeta, et al., 2012). Common varieties of onion include red Tropicana, Bombay red (brown onion), white onion among others (Nuutila et al., 2003). Onion (Allium cepaL.) has been revered through the ages not only for its culinary uses but also for its therapeutic properties. Nigeria is the largest producer in West Africa with a total production of slightly above 1.1 million tonnes; however, more than $50 \%$ loss occurred during storage of fresh onion (FAO, 2015). About $50 \%$ of onions produced in 2010 under irrigation and rain fed cultivation in Nigeria were from Kano State, Nigeria (Muhammad, 2018). Remarkably known for its aroma, taste and lachrymatory effects, onion plays significant role in the industries as constituents for moth repellent, beverages, expectorants as well as condiment in biscuits (Sharma et al., 2005). Studies have shown that bioactive molecules such as phenolic compounds in onions contribute in lowering bone resorption, and in prevention of degenerative diseases due to some significant number of polyphenols and potential antioxidant activity (Nuutila et al., 2003). Onions have been evaluated for considerable nutritional value such as lipid, protein, reducing sugar, iron, calcium, vitamin C (Anju et al., 2010), phenolic contents as well as antioxidant activity (Cheng, et al., 2013).

Dehydration or drying of foods can be described as any process that involves thermal removal of volatile substances to obtain a dry solid (Anju, 2010). Due to a high demand for onions especially in Europe, dehydrated onions in powdered form, canned onion and onion pickles have gained recognition in world trade (Srinivasa and Sabramanyam, 1999). Onion dehydration is 


\section{Bala et al: Nutritional Quality Evaluation of Stored Onion (Allium cepa L.) Powder...}

aimed at limiting the moisture content in the food matrix to prevent microbial spoilage of its nutritional and organoleptic properties (ArayaFarias and Ratti, 2009), to increase its shelf life, improve quality, simplify handling, storage and transportation as well as making condiments in some confectionery products in food processing (Bawa, et al., 2007). As a seasonal crop, price tends to skyrocket during off-season, so, attempts made to store and minimize spoilage of onion is still not very efficiently practiced among farmers in Africa. The high moisture content is thought to play a role in microbial infestations of onions during storage (Akbari, 2001).

This study aimed to determine the effect of light transparency packaging material on total phenolic contents, proximate composition and microbial count of onion powder during and after storage

\section{MATERIALS AND METHODS}

\section{Sample Collection and Preparation}

Red onion (Allium cepa) variety commonly known as yan gashua in Hausa language was purchased directly from onion farmers at Kura local government, Kano in January, 2020. After sorting, the onion bulbs were blanched in hot water containing $2.5 \%$ normal saline solution for 5-10 minutes and then sliced to about $2 \mathrm{~mm}$ thickness using vegetable slicer and then drained. The sliced onion bulbs were thereafter dried using food dehydrator (BOSCH BS-6612) set at $60^{\circ} \mathrm{C}$ for 24 hours (Anju, 2010). The dried slices were finely blended into powder form and exactly $300 \mathrm{~g}$ was weighed and packaged in each of 12 glass jars of which six were ambered coloured while the other six were transparent. Analyses of sample were carried out on monthly basis for total polyphenolic contents and every three months for proximate composition and microbial count.

\section{Proximate Analyses of Onion Powder}

The proximate analyses of the crude fibre, fat, crude protein, carbohydrate, as well as moisture and ash contents were analysed in line with standard protocols of analyses (AOAC, 2007) for the first, third and sixth month of storage.

\section{Sample Extraction and Determination of Total Polyphenol}

Exactly $500 \mathrm{mg}$ of onion powder was added to 25 $\mathrm{ml}$ of $80 \%$ methanol then sonicated for 1 hour. The mixture was then centrifuged at 3000 RPM for 30 minutes and extract was collected twice after being spun for the second time into Eppendorf tubes wrapped with aluminium foil left at room temperature while analyses followed up immediately. Total polyphenols contents (TPC) of onion powder were determined prior to storage and for the stored samples of the onion powder in amber and transparent storage jars according to the methods described by Lachman et al. (2003) and were expressed in milligrams gallic acid equivalent (mg/g GAE) of dried weight matter.

A stock solution of $250 \mathrm{mg} / \mathrm{L}$ gallic acid was prepared then serially diluted to obtain concentrations of 50,100, 150 and $200 \mathrm{mg} / \mathrm{L}$ following methods of Atawodi et al. (2011). Absorbance was taken at $765 \mathrm{~nm}$ for each of 0.25 $\mathrm{mL}$ of the standard solutions to obtain a calibration curve. Similarly, $0.25 \mathrm{ml}$ of $500 \mathrm{mg} / \mathrm{Lof}$ each sample was added to $2.5 \mathrm{ml}$ FolinCiocalteu Reagent (FCR) followed by $2.0 \mathrm{~mL}$ of $1 \mathrm{M}$ sodium carbonate. The reaction mixtures were allowed to stand at room temperature for 15 minutes in a dim lighted room. Absorbance was then measured spectrophotometrically at $765 \mathrm{~nm}$ using a T80 PG-UV/Nis spectrometer while $0.25 \mathrm{~mL}$ of methanol-water (50:50) was used as blank. TPC was expressed as gallic acid equivalent (GAE) $\mathrm{mg} / \mathrm{g}$ dry weight (DW) of sample estimated using the equation: $y=0.0053 x+0.0023$ obtained from the calibration curve of gallic acid standard.

\section{Microbial Analysis}

Microbial counts were carried out on the dried onion sample from different storage jars as described by APHA, (2001). Exactly $1.0 \mathrm{~g}$ of onion powder was prepared in $9 \mathrm{~mL}$ of peptone water and $1 \mathrm{~mL}$ of the stock solution was serially diluted up to $10^{-4}$ in $9 \mathrm{~mL}$ of peptone water. 
About $0.1 \mathrm{~mL}$ aliquots were spread on plated nutrient agar (NA), MacConkey agar (MCA) and potato dextrose agar (PDA) for the enumeration of aerobic viable bacteria, coliforms and fungi respectively. The innoculated NA and MCA plates were incubated at $37^{\circ} \mathrm{C}$ for 48 hours while the PDA plates were incubated at room temperature for 7 days. Fungal growth was observed by physical observation and lactophenol cotton blue staining technique as described by Alexopoulus and Mims (1979).

The colonies were then counted and expressed as colony forming units per gram (cfu/g) of samples. Observed colonies were subcultured repeatedly on media used for primary isolation to establish pure cultures. All counts were done in duplicate using Stuart scientific colony counter. Isolates of bacteria were identified based on colony morphology, Gram stain reactions and biochemical characteristics was in accordance with established standard protocols for known taxa as in Bergey's Manual of Systematic Bateriology (Holt et al., 1994).

\section{Data Analysis}

Experimental analyses were carried out in triplicate and data were expressed as means \pm standard deviation. Data were analyzed using the t-test (SPSS 16.0 version 2007) to determine the statistical significance $(p<0.05)$.

\section{RESULTS AND DISCUSSION}

\section{Total Polyphenol Contents (TPC)}

The results of total polyphenol contents of onion powder stored in amber and transparent jars are presented in Table 1. Before storage, the TPC was evaluated to be $14.60 \pm 1.08 \mathrm{GAE}(\mathrm{mg} / \mathrm{g})$ dry weight of onion powder sample used. The TPC values decreased with time of storage in both type of storage materials but a significant $(p<$ 0.05 ) difference in the level of total polyphenol contents of the stored onion powder in the amber and transparent jars was however observed. That is, $5.92 \pm 0.76 \mathrm{GAE} \mathrm{mg} / \mathrm{g}$ for TPC in amber jar as compared with $1.64 \pm 0.78 \mathrm{GAE} \mathrm{mg} / \mathrm{g}$ in transparent jar. This implies a reduction of $59.5 \%$ and $88.8 \%$ in TPC as recorded in amber and transparent storage jars, respectively at the end of six moth storage.

Total polyphenol contents of foods tend to decline due to processing and storage (Judita et al., 2014; Cieslik et al., 2006). The rate of decline in the content of total polyphenols in this study was greater after the third month of storage in the transparent jars. This may be probably due to the prevailing weather conditions which made the room temperature higher around April in the northern part of Nigeria.

Total polyphenols content of onion powder is sensitive to light, heat, variety of onion and the method of dehydration (Anju et al., 2010; Chang et al. 2013). When onion is subjected to dehydration or stored in material that allows the passage of light, deterioration of bioactive components such as phenolics and flavonoids are imminent due to cleavages of esterified and glycosylated bonds (Maillard, 1988).

Table 1: Level of total polyphenol contents of onion powder during storage

\begin{tabular}{lcc}
\hline $\begin{array}{l}\text { STORAGE TIME } \\
\text { (MONTHS) }\end{array}$ & $\begin{array}{c}\text { AMBERED JARS } \\
\text { GAE }(\mathbf{m g} / \mathbf{g})\end{array}$ & $\begin{array}{c}\text { TRANSPARENT JARS } \\
\text { GAE }(\mathbf{m g} / \mathbf{g})\end{array}$ \\
\hline $\mathbf{0}$ & $14.60 \pm 1.08^{\mathrm{a}}$ & $14.60 \pm 1.08^{\mathrm{a}}$ \\
$\mathbf{1}$ & $13.72 \pm 0.21^{\mathrm{d}}$ & $12.72 \pm 0.38^{\mathrm{e}}$ \\
$\mathbf{2}$ & $11.34 \pm 1.32^{\mathrm{f}}$ & $9.96 \pm 0.96^{\mathrm{h}}$ \\
$\mathbf{3}$ & $9.20 \pm 0.34^{\mathrm{e}}$ & $8.69 \pm 0.22^{\mathrm{c}}$ \\
$\mathbf{4}$ & $8.06 \pm 0.94^{\mathrm{c}}$ & $4.54 \pm 0.94^{\mathrm{b}}$ \\
$\mathbf{5}$ & $7.56 \pm 1.16^{\mathrm{b}}$ & $2.40 \pm 0.94^{\mathrm{d}}$ \\
$\mathbf{6}$ & $5.92 \pm 0.76^{\mathrm{h}}$ & $1.64 \pm 0.78^{\mathrm{f}}$ \\
\hline
\end{tabular}

Values are data expressed as mean \pm SD of three replicates. Different superscript in the same row indicates significant difference at $p<0.05$. DW $=$ dried weight of sample. 


\section{Bala et al. Nutritional Quality Evaluation of Stored Onion (Allium cepa L.) Powder...}

\section{Proximate Composition and Energy Content}

Results of proximate composition of onion powder stored in amber and transparent jars are presented in Table 2. There were significant $(p<$ $0.05)$ differences in the proximate composition of onion powder stored in amber and transparent jars. Moisture content ranged from initial $2.19 \pm$ $0.01 \%$ before storage to $8.12 \pm 0.83 \%$ and $7.22 \pm 0.12 \%$ in amber and transparent jars, respectively at the end of storage. The onion powder contained in amber jars had more moisture (about 0.9\%) higher than those in transparent jars. This could probably be associated with the principle of heat transfer that dull or black objects absorb more heat, while transparent objects reflect more heat. Moisture content therefore, is an important parameter in flour (powder) which significantly affect shelf life of food products. Flour or powder products with moisture content less than $13 \%$ are less affected from moisture dependent deterioration (Shahzadi et al., 2005).

After the sixth month of storage, crude fiber contents of onion powder in amber and transparent storage jars increased by $0.33 \%$ and $0.26 \%$, respectively against the initial value of $5.93 \pm 0.01 \%$ before storage. Consumption of fiber containing food products has been linked to reduction in hemorrhoids and obesity (Chukwu et al., 2013). The protein content as evaluated increased from initial $7.51 \pm 0.07 \%$ before storage to $9.58 \pm 0.08 \%$ and $9.19 \pm 0.06 \%$ in amber and transparent jars, respectively. The more protein recorded with the amber jar content probably correlate with the more moisture content evaluated in the amber jars. The level of water sorption had been reported to influence the stability of protein in solid state (Micheal, 1988). Ash content was evaluated to have a downward trend after the third and sixth month of onion storage in both jars. The ash content of onion powder in the transparent jars decrease more to about $7 \%$ lesser than for those onion powder in amber jars at the end of storage. Fat content ranged from $0.63 \pm 0.01 \%$ before storage to $0.48 \pm 0.01 \%$ and $0.45 \pm 0.02 \%$ in amber and transparent jars after the sixth month of storage.
Food containing less amount of fat stays longer in storage because, high amount of fat could lead to unpleasant smell caused by rancidity during storage (Gupta and Shukla, 2017).

Carbohydrate contents decreased in both storage jars at the end of the sixth month of storage. There were $6.59 \%$ and $8.05 \%$ reduction in carbohydrate contents of onion powder in transparent and amber jars from the initial $82.85 \%$ before storage. The decrease of carbohydrates could be due to breakdown of carbohydrates sub-units in a reaction which is temperature dependent and extensively on intermediate water activities. This was more observed with amber jars where moisture contents were higher as a result of more heat absorption from the environment. The energy value was estimated to have dropped by $6.88 \%$ and $5.79 \%$ from onion powder stored in amber and transparent jars, respectively from the initial value of $367.11 \mathrm{Kcal} / \mathrm{g}$ before storage. The more energy value in the onion powder stored in transparent jars is associated with the more carbohydrate content.

\section{Microbial Assays}

The total plate count (cfu/g) for microbial load analysis is presented in Table 3. It was observed that no growth (NG) was noticed in the zeroth month until the third and sixth months of storage. At the third months of storage, there were more fungal counts $\left(7.0 \times 10^{2} \mathrm{cfu} / \mathrm{g}\right)$ in the transparent glass jar than recorded for the stored onion powder in the amber colored glass jars $(2.0 \mathrm{x}$ $10^{2} \mathrm{cfu} / \mathrm{g}$. Likewise, more bacteria were recorded in the stored onion powder in transparent jars (3.0 $\left.x 10^{2} \mathrm{cfu} / \mathrm{g}\right)$ than in the amber colored glass jars $\left(1.8 \times 10^{1}\right)$ at the end of the third months. At the end of the study period (sixth month) of storage, similar trend continued of more microbial counts in transparent glass jars $\left(3.5 \times 10^{3} \mathrm{cfu} / \mathrm{g}\right.$ and $6.1 \mathrm{x}$ $10^{5} \mathrm{cfu} / \mathrm{g}$ bacterial and fungal, respectively) than was recorded for stored onion powder in amber glass jars $\left(2.1 \times 10^{2}\right.$ and $3.0 \times 10^{3}$ bacterial and fungal, respectively. Beside blanching and salting which were pretreatment during preparatory 
Nigerian Journal of Basic and Applied Science (December, 2021), 29(2): 09-16

stage, minimal microbial growth in the stored onion powder evaluated in the third and sixth months of storage could also be due to onion inherent antimicrobial properties attributed to the quercetin and some ample amount of allicin contents (Gupta and Shukla, 2017; Ankri and
Mirelman, 1999). Isolated species from sample after blanching and salting could probably be of heat and salt resistant (Kadam et al., (2009).

Table 2: Proximate composition of dried onion powder stored in amber and transparent glass jars

\begin{tabular}{lccc}
\hline $\begin{array}{l}\text { PROXIMATE } \\
\text { PARAMETERS (\%) }\end{array}$ & $\begin{array}{l}\text { STORAGE } \\
\text { (MONTH) }\end{array}$ & $\begin{array}{c}\text { TIME } \\
\text { AMBERED } \\
\text { JARS }\end{array}$ & $\begin{array}{l}\text { TRANSPARENT } \\
\text { JARS }\end{array}$ \\
\hline MOISTURE CONTENT & $0^{\text {th }}$ & $2.19^{\mathrm{a}}$ & $2.19^{\mathrm{a}}$ \\
& $3 \mathrm{rd}$ & $3.88^{\mathrm{b}}$ & $3.75^{\mathrm{c}}$ \\
CRUDE FIBRE & $6^{\text {th }}$ & $8.12^{\mathrm{c}}$ & $7.22^{\mathrm{d}}$ \\
& $0^{\text {th }}$ & $5.93^{\mathrm{b}}$ & $5.93^{\mathrm{b}}$ \\
CRUDE PROTEIN & $3 \mathrm{rd}$ & $5.99^{\mathrm{a}}$ & $5.95^{\mathrm{c}}$ \\
& $6^{\text {th }}$ & $6.26^{\mathrm{e}}$ & $6.19^{\mathrm{b}}$ \\
& $0^{\text {th }}$ & $7.51^{\mathrm{c}}$ & $7.51^{\mathrm{c}}$ \\
ASH CONTENT & $3^{\mathrm{rd}}$ & $8.89^{\mathrm{a}}$ & $8.85^{\mathrm{d}}$ \\
& $6^{\text {th }}$ & $9.58^{\mathrm{c}}$ & $9.19^{\mathrm{a}}$ \\
FAT CONTENT & $0^{\text {th }}$ & $0.89^{\mathrm{d}}$ & $0.89^{\mathrm{d}}$ \\
& $3 \mathrm{rd}$ & $0.85^{\mathrm{a}}$ & $0.81^{\mathrm{c}}$ \\
CARBOHYDRATE & $6^{\text {th }}$ & $0.76^{\mathrm{b}}$ & $0.69^{\mathrm{a}}$ \\
CONTENT & $0^{\text {th }}$ & $0.63^{\mathrm{e}}$ & $0.63^{\mathrm{e}}$ \\
& $3 \mathrm{rd}$ & $0.60^{\mathrm{a}}$ & $0.59^{\mathrm{b}}$ \\
& $6^{\text {th }}$ & $0.48^{\mathrm{c}}$ & $0.45^{\mathrm{d}}$ \\
ENERGY & $0^{\text {th }}$ & $82.85^{\mathrm{f}}$ & $82.85^{\mathrm{f}}$ \\
(KCal/g) & $3^{\text {rd }}$ & $79.79^{\mathrm{a}}$ & $80.83^{\mathrm{b}}$ \\
& $6^{\text {th }}$ & $74.80^{\mathrm{a}}$ & $76.26 \mathrm{c}$ \\
& & & \\
& $0^{\text {th }}$ & 367.119 & 367.119 \\
& $3 \mathrm{rd}$ & $360.12^{\mathrm{a}}$ & $364.03^{\mathrm{a}}$ \\
& $6^{\text {th }}$ & $341.84^{\mathrm{c}}$ & $345.85^{\mathrm{e}}$ \\
\hline
\end{tabular}

The values are means of three replicates. Different superscript in the same row indicates significant difference at $p<0.05$.

Table 3: Total plate count of dried onion samples during storage

\begin{tabular}{llll}
\hline $\begin{array}{l}\text { STORAGE TIME } \\
\text { (MONTH) }\end{array}$ & AMBERED JARS & TRANSPARENT JARS & MICROBES TYPE \\
\hline $\mathbf{0}$ & $\mathrm{NG}$ & $\mathrm{NG}$ & \\
3 & $1.8 \times 10^{1}$ & $3.0 \times 10^{2}$ & Bacteria \\
6 & $2.1 \times 10^{2}$ & $3.5 \times 10^{3}$ & Bacteria \\
0 & $\mathrm{NG}$ & $\mathrm{NG}$ & \\
3 & $2.0 \times 10^{2}$ & $7 \times 10^{2}$ & Fungi \\
6 & $3.0 \times 10^{3}$ & $6.1 \times 10^{5}$ & Fungi \\
\hline
\end{tabular}


Bala et al: Nutritional Quality Evaluation of Stored Onion (Allium cepa L.) Powder...

Table 4: Microscopic description of isolated organisms

\begin{tabular}{lll}
\hline \multicolumn{1}{c}{ PHYSICAL OBSERVATION } & MICROSCOPIC OBSERVATION & ORGANISM \\
\hline $\begin{array}{l}\text { Black colonies with dotted grey } \\
\text { on its apex }\end{array}$ & $\begin{array}{l}\text { Filamentous, thick septate } \\
\text { hyphae, conidia appeared in } \\
\text { chains from the sterigmata } \\
\text { Oval shaped with short } \\
\text { Creamy colonies }\end{array}$ & Aspergillus species \\
$\begin{array}{l}\text { Golden yellow and pale-pink budding } \\
\text { colonies }\end{array}$ & $\begin{array}{l}\text { Circular and grape-like cluster } \\
\text { Fuzzy white, slight yellow } \\
\text { colonies. }\end{array}$ & $\begin{array}{l}\text { Presumed Staphylococcus } \\
\text { species. }\end{array}$ \\
\hline
\end{tabular}

Tables 4 and 5 showed the morphological description of the isolated microbes and the biochemical tests of isolated bacteria. Two fungi species (aspergillus and yeast) were identified with the stored onion powder from the third month of storage in both storage materials. Similarly, Bacillus and Staphylococcus species were identified after morphological and biochemical characteristics and also identified after the third month of storage in both jars. Based on guidelines contained in the ICMSF revised edition (2014), the level of colony countsfor all the species of organisms isolated from the stored onion powder are still in the safe level since of the counts had up to an infective dose of $\geq 10^{7} \mathrm{cfu} / \mathrm{g}$.

Table 5: Biochemical test of isolated bacteria

\begin{tabular}{|c|c|c|c|c|c|c|c|}
\hline BACTERIA & $\begin{array}{l}\text { GRAM } \\
\text { REACTION }\end{array}$ & $\overline{\text { CAT }}$ & IND & $\overline{M R}$ & MOT & CIT & $\overline{C O A}$ \\
\hline $\begin{array}{l}\text { STAPHYLOCOCCUS } \\
\text { SPECIES }\end{array}$ & + Cocci & + & - & - & - & - & + \\
\hline BACILLUS SPECIES & + Rod & + & - & - & - & - & + \\
\hline
\end{tabular}

+ = positive to test; $=$ = negative to test; $\mathrm{CAT}=$ catalase; $I \mathrm{ND}=$ indole; $\mathrm{MR}=$ methyl red; $\mathrm{MOT}=$ Motility; $\mathrm{ClT}=$ citrate; $\mathrm{COA}=$ coagulase.

\section{CONCLUSION}

The stored onion powder produced from red variety of northern Nigeria was evaluated for total polyphenols contents, proximate analyses and microbial loads before, during and after storage in amber and transparent jars. Results obtained from this study proved that amber storage jars are better than transparent storage jars. This perception is due to the more retention in the contents of total polyphenolic and proximate parameters recorded during the storage period of six months. Microbial counts in both jars were within safe levels nevertheless, fewer counts were recorded in the stored onion powder of amber storage jars. For enhanced utilization of onion in terms of value addition and to minimize postharvest wastage of fresh onion bulbs, findings from this current study suggest that when onion powder is produced and considered for storage for home or industrial use, amber coloured storage materials should be preferred to transparent material for better nutritional quality retentions.

\section{ACKNOWLEDGEMENTS}

The authors wish to acknowledge Nigerian Stored Products Research Institute Laboratory, Kano and Biochemistry Laboratory of Bayero University, Kano for providing enabling supports for the success of this research. 


\section{REFERENCES}

Alexopoulus, C. J., \& Mims, C.W. (1979). Introductory Mycology, $3^{\text {rd }}$ ed. Wiley, New York, Pp. 129.

Atawodi, S.E., Adekunle, O.O., \& Bala, I. (2011). Antioxidant, Organ Protective and Ameliorative Properties of Methanolic Extract of Anogeissus Leiocarpus Stem Bark Against Carbon TetrachlorideInduced Liver Injury. International Journal of Pharmaceutical Sciences and Research (IJPRS), 2(6): 1443-1448.

Bawa, A.S., Khanum, F., Sanitha, V., \& Kuma, A. (2007). Effect of Cooking on Total, Polyphenols, Flavonoids and Antioxidant Activity of Spices in India Culinary. Journal of Food Science and Technology, 44(4): 357-359.

Anju, S., Kawatra, A., \& Salil, S. (2010): Nutritional Evaluation of Onion Powder Dried Using Different Drying Methods. Journal of Dairying Foods, 29 (2):151153.

Ankri, S., \& Mirelman, D. (1999): Antimicrobial properties of Allicin. Journal of Microbes and Infection, 1(2): 125-129.

APHA, (2001): Compendium of Methods for the Microbial Examination of Foods. American Public Health Association, $4^{\text {th }}$ ed. Washington DC., USA. Pp. 11101121.

AOAC. (2007). Official Methods of Analysis and Calculations Methods 936.06 Fruits, Vegetables and their Products, Association of Analytical Communities, Gaithersburg.

Araya-Farias, M., \& Ratti, C. (2009). Dehydration of Foods: General Concepts in Advances in Food Dehydration, 5th ed. CRC Press, Boca Raton, USA. p.206.

Akbari, S. H., Patel, N.C., \& Joshi, D.C. (2001). Studies on Dehydration ofOnion. ASAE International Annual Meeting. Sacramento, California, USA.

Chang, A., Chen, X., Jin, Q., Wang, W., Shi, J., \& Liu, Y. (2013). Comparison of Phenolic Contents and Antioxidant Capacity of
Red and Yellow Onions. Journals of Food Sciences, 31(5): 501-508.

Chukwu, B.N., Ezebuiro, V.O., Samuel, E.S., \& Nwachukwu, K.C. (2013). Gender Differential in the Incidence of Diabetes Mellitus Among Patients in Udi Local Government of Enugu State, Nigeria. Meditteranian Journal of Social Science, 4(1): 131-138

Cieslik, A., Greda, A., \& Adamus, W. (2006): Contents of Polyphenols in Fruits and Vegetables. Journal of Food Chemistry, 9(4): 135-142.

Food and Agriculture Organisation (2015). Food and Agriculture Organization of the United Nations. Food Security Statistics Nigeria. faostat.fao.org.

Gupta, N., \& Shukla, R.N. (2017). Preparation and Quality Evaluation of Dehydrated Carrot and Onion Slices. Journal of Food Process Technology, 8(9): 1000-1018.

Holt, J. G., Krieg, N.R., Sneath, P. H. A., \& Staley, J.T. (1994). Bergey's Manual of Determinative Bacteriology,9th ed. Williams and Wilkins, Baltimore, Md, USA, Pp. 233.

International Committee of Microbiological Specification for Foods (ICMSF) In: Microbiological Guideline for Foods (2014). Centre for Food Safety. Queensway, Hong Kong.

Jayeeta, M., Shanker, L.S., \& Pavuluri, S.R. (2012). Onion Dehydration: A Review. Journal of Food Science and Technology, 49(3): 267-277.

Judita, B., Janette, M., Petra, K., \& Beata, V. (2014). The Influence of Sulphur on the Content of Total Polyphenol and Antioxidant Activity in Onion (A. Cepa). Journal of Microbiology Biotechnology and Food Science, 3(2): 199-201.

Kadam, D.M., Nangare, D.D., \& Oberol, H.S. (2009): Influence of Pre-treatment on Microbial Load of Stored Dehydrated Onion Slices. International Journal of Food Science and Technology, 44(10): 1902-1908. 


\section{Bala et al: Nutritional Quality Evaluation of Stored Onion (Allium cepa L.) Powder...}

Muhammad, N.A., Kabiru. M.K., Umar, R.S., Mustapha, M. (2018). Assessment of Marketing Performance in Major Onion Markets in Kano State, Nigeria. International Journal of Science and Research, 7(8): 1633-1636.

Lachman, J., Pronek, A., Helmtankova, A., Dudjak, V., Pirec, K. and Faitova, C. (2003). Total Polyphenols and Flavonoids Antioxidants in Different Onion Varieties. Journal of Horticulture Science, 30 (4): 142-147.

Maillard, L.C. (1988). The Role of Moisture in Protein Stability. Journal of Drug Development and Industrial Pharmacy, 14(14): 2047-2070.

Nuutila, A., Puupponen-Pimia, R., Aarni, M., \& Oksman-Caldentey, K.M. (2003). "Comparison of Antioxidant Activity of Onion and Garlic Extracts by Inhibition of
Lipid Peroxidation and Radical Scavenging Activity", Journal of Food Chemistry, 81(4): 485 - 493,

Shahzadi, N., Butt, M.S., Rehman, S.U., \& Shariff, K. (2005). Chemical Characteristics of Various Composite Flours. International Journal of Agriculture and Biology. 7(3): 105-108.

Sharma, S., Deya, E., Frau, M., \& Rossello, C. (2005). Simple Modeling of Air-Drying Curves of Fresh and Osmotically Predehydrated Apple Cubes. Journal of Food Processing and Engineering, 3(3):139-150.

Srinivasa, M. D., \& Sabramanyam, K.V. (1999). Onion Export Markets and their Stability for Increasing India's Exports. Journal of Agricultural Economics and Research, 12(2): 118-128. 